\title{
НАУКОВА СКЛАДОВА КРИМІНОЛОГІЧНОГО ЗАБЕЗПЕЧЕННЯ ЕКОНОНОМІЧНОЇ БЕЗПЕКИ ДЕРЖАВИ
}

\author{
САЗОНОВ Василь Вікторович - кандидат юридичних наук докторант \\ Харківського національного університету внутрішніх справ \\ DOI:10.32782/LAW.2020.1.13 \\ УДК 343.97-048.66:323.2
}

Статтю присвячено визначенню ролі науки в теоріі і практиці кримінологічного забезпечення економічної безпеки держави.

Наголошено на актуальності дослідження изього напрямку кримінологічного забезпечення, що обумовлено ребормаційними перетвореннями та постійними законодавчими змінами у регулюванні питань, пов'язаних із забезпеченням економічної безпеки. Виділено ряд основних заходів, які слід реалізовувати в площині науково - методичного забезпечення економічної безпеки держави.

Підкреслено виключне значення тісноӥ взаємодї науки і практики протидї злочинності на шляху до забезпечення економічної безпеки. Наголошено на тому, що на съогоднішній день впровадження результатів наукових досліджень у практичну діяльність прачівників підрозділів Національної поліиї України, слід розглядати як суттевий бактор підвищення ефбективності правоохоронної діяльності, який, нажаль, використовується в практиці протидї злочинності не в повній мірі.

Акцентовано увагу на необхідності інтенсифікачї̈ науковоӥ розробки широкого кола актуальних питань в сбері протидї економічній злочинності, як одній з основних загроз економічній безпещі держави з одного боку, та бормуванні кримінально - правової політики на основі якісно нового наукового кримінологічного підгрунтя - з іншого.

Підкреслено пріоритетність державної підтримки розвитку наукової діяльності (відомчой, в тому числі) в Украӥні, необхідність забезпечення участі наукових прачівників у бормуванні основних напрямків начіональної політики в сбері наукових розробок.

Окреслено коло перспективних для подальших наукових розвідок напрямків, зокрема: математичне забезпечення, мотивачійне, антикризове, економічне, технологічне, програмне й інші види забезпечення економічної безпеки країни.

Ключові слова: економічна безпека, економічна злочинність, кримінологічне забезпечення, наука, наукове забезпечення, порівняльна кримінологія, науковий потенціал, наукова діяльність, впровадження.

\section{Постановка проблеми}

Стан справ у вітчизняній соціально-економічній сфері свідчить про те, що рівень економічної безпеки України, незважаючи на вжиті заходи, й досі залишається на небезпечній позначці. Ситуація, що склалася, вимагає від суспільства та держави вжиття невідкладних комплексних заходів, які забезпечать нормальний рівень життя населення й гарантують його соціальну захищеність, здатність економіки функціонувати в режимі розширеного відтворення, стійкість фінансової системи, раціональну структуру зовнішньої торгівлі та збереження єдиного економічного простору й широких міжрегіональних економічних відносин. При цьому основними напрямками, за якими повинна бути сформована система кримінологічного забезпечення економічної безпеки країни, 6 нормативно-правовий, організаційно-управлінський, інформаційно-аналітичний та на- 
уково - методичний. Вони являють собою елементи цілісної системи кримінологічного забезпечення протидії економічній злочинності.

Зважаючи на те, що наука є визначальним чинником прогресу суспільства, підвищення добробуту громадян, їх духовного та інтелектуального зростання, вважаємо за необхідне більш детально розглянути їі роль у механізмі кримінологічного забезпечення економічної безпеки держави.

Економічна безпека держави, як одна із складових національної безпеки, є досить широко дослідженою. Ці питання знайшли відображення в роботах спеціалістів різного профілю. В юридичній літературі ці проблеми висвітлені в працях таких вчених як О. М. Бандурки, В. Т. Білоуса, А. М. Бойка, О. М. Бусол, Б. М. Головкіна, А. О. Горщака, В. Б. Дацюка, Г. Ю. Дарнопих, О. Г. Кальмана, В. В. Коваленка, О. М. Литвинова, М. Г. Максіменцева, Л. К. Малахова, I. В. Маслія, С. А. Мозоля, Ю. В. Нікітіна, Ю. В. Орлова, В. М. Поповича, Е. Л. Стрельцова, О. А. Туєва, Ю. А. Турлової, І. О. Христич й деяких інших.

Метою даної публікації 6 визначення ролі науки, зокрема кримінологічної, в механізмі кримінологічного забезпечення економічної безпеки.

\section{Виклад основного матеріалу}

Науково-методичний напрям кримінологічного забезпечення протидії економічній злочинності є базовою субстанцією та запорукою підвищення його ефективності. XXI століття в світі знаменується радикальними змінами всіх сфер життедіяльності суспільства. Це і демографічні зміни, і міграційні процеси, і кіберзлочинність, і кібервійни, а також зміни в економіці, інформаціно - технологічній сфері, політиці, моралі. При чому ці процеси динамічні і невпинні, злочинність набуває нових форм вкрай небезпечних і глобальних. В цій досить складній ситуації важливим моментом виступає здатність суспільства, держави і їі інституцій своєчасно зрозуміти нові виклики та загрози, протиставити їм нові шляхи вирішення, нові можливості їх подолання.
I центральну роль в цьому процесі відіграє наука. Наука - це сфера людської діяльності, спрямована на вироблення нових знань про природу, суспільство і мислення. Необхідність наукового підходу до всіх видів людської діяльності змушує науку розвиватися швидшими темпами, ніж будь-яку іншу галузь діяльності [1, с.4].

Наукова складова кримінологічного забезпечення економічної безпеки держави являє собою вагомий його сегмент, адже ефективність протидії злочинності залежить від ступеня наукового забезпечення та аналітичного супроводження на усіх рівнях, інтенсивності взаємодії вчених і практиків різних дотичних галузей науки у справі формування узгодженого інтегрованого цілісного наукового продукту. Негативні процеси і тенденції, які відбуваються в Україні, вимагають постійного наукового відстеження, глибокого і детального дослідження криміногенної обстановки, внесення відповідних коректив у стратегію і тактику протидії злочинності [2, с.6].

Слід мати на увазі, що сучасна економічна злочинність $е$ злочинністю кризового типу. 3 одного боку вона продукується соціальною кризою та часто необгрунтованим реформаторством в Україні, з іншого - вона є підгрунтям для поглиблення існуючої кризи. Взаємозв'язок цих процесів очевидний, а тенденція до транснаціоналізації цього виду злочинності створюе реальну загрозу національній безпеці України. Тому першочерговою задачею загальнодержавного рівня повинна стати протидія цьому виду злочинності як соціальній проблемі, і базуватися вона повинна на глибокому і всебічному осмисленні соціальних законів розвитку суспільства, носити широкомасштабний, комплексний, науково - пізнавальний та практичний характер. Наука виступає провідником на шляху до реалізації державної політики в сфері протидії економічній злочинності, удосконаленні чинного законодавства, вивченні зарубіжного досвіду, успішній протидії сучасним загрозам і небезпекам суспільству i державі. Потужний науковий потенціал є запорукою успішної політики держави в означеній сфері. I в даному випадку наука є елементом політики, бо вона підвищує результативність в досягненні мети. 


\section{Кримінальне право, кримінальний процес та криміналістика}

Саме кримінологія взяла на себе задачу відстежувати негативні зміни в розвитку суспільства, аналізувати кримінальні процеси, що відбуваються в різних соціальних сферах, інформувати суспільство про тенденції їх розвитку.

Більшість проблем, що вивчаються кримінологами, розглядаються, насамперед, у прикладному аспекті. Варто визнати, що великою заслугою сучасної кримінології $\epsilon$ те, що накопичено величезний масив статистичних даних, проаналізовані різні аспекти організації профілактичної діяльності щодо окремих видів злочинів. Зазначено нові тенденції в розвитку злочинності, тісно пов'язані з розвитком сучасного суспільства [3, с.65].

Кримінологічна теорія як сукупність ідей, поглядів, концепцій, учень, уявлень про об'єкти соціальної дійсності грунтується на практиці кримінологічного дослідження та вивчення ефективності боротьби зі злочинністю. Перебуваючи в органічній єдності 3 практикою, вона постає системою консолідуючих знань про злочинність, зведених до єдиної спільної основи [4, с.73].

Кримінологічне пізнання органічно включає у зміст самого знання суб'єктивний момент, що привноситься не тільки і навіть не стільки дослідником, скільки самим об'єктом наукового пізнання. Людський фактор пояснюе відому прихильність багатьох смислових значень і формулювань науки до конкретних історичних умов, що не може не позначитися на істинності самого знання. Системи людських зв'язків складні, тому точний опис зворотних зв'язків ускладнений необхідністю врахування таких етапів, як переробка інформації, прийняття рішень і т. д., розгортання яких серйозно видозмінюе ситуацію, роблячи їі важко планованою і важко передбачуваною.

Важливу роль у цьому процесі відіграють кримінологічні дослідження, основною метою яких є виключення несуттєвих, випадкових ознак свого об'єкта. Те, що залишається - є феноменологічним залишком, абсолютною сутністю, тобто інваріантним описом результату пізнання. Таким чином, інфільтрується максимальна кількість суб'єктивних нашарувань на понятті, що часто стають результатом термінологічної «засміченості» сучасної кримінологічної науки, та невідворотними процесами суб'єктивізації наукового пошуку. Відтак, кристалізується поняття у спосіб, що дозволяє нівелювати значення несуттєвих ознак, підкресливши суттєві, i таким чином, наблизитись до розуміння феномену - будь-то злочин, злочинність чи особистість злочинця - розмежувавши та, водночас, пов'язавши їх зовнішні прояви i сутнісні ознаки [5].

Однак, досі влада і суспільство покладають усі сподівання із протидії злочинності виключно на систему органів кримінальної юстиції, котра поглинає мільйони бюджетних асигнувань, а істотних зрушень у забезпеченні правопорядку не спостерігається. Відчувається недостатність потужностей кримінологічних знань, з одного боку, і відсутність політичної волі - 3 другого, у залученні кримінологічної науки до законотворчості, впровадження наукових розробок і рекомендацій при вирішенні загальнодержавних управлінських завдань. Дається взнаки брак засадничих розробок кримінологічної складової політики держави у сфері запобігання та протидії злочинності [6, с.237]. Тому раціональне залучення наукової спільноти у тісній взаємодії з практичними працівниками до процесу формування державної політики у сфері протидії злочинності є соціально обумовленим та практично затребуваним.

Основними заходами науково - методичного супроводу організації кримінологічного забезпечення діяльності територіальних органів поліції $\epsilon$ розробка методичних матеріалів, що містять рекомендації зі збору та накопичення кримінологічної інформації, проведення аналізу кримінальної обстановки на території обслуговування, формування прогнозних оцінок і надання їх суб'єктам кримінологічного забезпечення територіальних органів поліції. Методика аналізу і оцінки злочинності на території оперативного обслуговування органу територіального поліції має містити набір методів, що дозволяють здійснити аналіз і оцінку факторів зовнішнього середовища, що впливають на злочинність та їі стан, соціально-демографічну характеристику осіб, що вчинили злочини, результатів оперативно-службової діяльнос- 
ті територіальних органів поліції, якісних і кількісних характеристик кадрового складу, стану законності та службової дисципліни, визначити пріоритети превентивної діяльності, ймовірний прогноз можливого розвитку кримінальної ситуації, результатів опитування громадської думки про діяльність територіального органу поліції [7, с.131].

До основних заходів, що слід вживати в площині науково - методичного забезпечення економічної безпеки, які на нашу думку сприятимуть підвищенню ефективності діяльності з протидії економічній злочинності і стабілізації криміногенної ситуації, слід віднести:

- розробка і впровадження єдиної концепції національної економічної безпеки, як науково - теоретичної основи економічної політики держави;

- запровадження практики проведення кримінологічної (наукової) експертизи законопроектів 3 питань протидії економічній злочинності;

- проведення порівняльних кримінологічних досліджень як за різними регіонами, країнами, правовими системами, так i міждисциплінарних;

врахування результатів та рекомендацій кримінологічних досліджень в процесі законотворчості та формуванні державної політики в сфері протидії злочинності;

- забезпечення тісної взаємодії між науковцями і практиками в процесі впровадження наукових результаів в правозастосовній діяльності (на всіх етапах);

- внесення науково - обгрунтованих пропозицій до відомчих і міжвідомчих нормативно - правових актів 3 протидії економічній злочинності;

- системний моніторинг законотворчої і правозастосовної діяльності;

- здійснення наукового відстеження стану та динаміки економічної злочинності, як основи для подальшого прогнозування i планування заходів протидії;

- інтенсифікація наукової розробки широкого кола актуальних питань протидії економічній злочинності, як одній 3 основних загроз економічній безпеці держави, 3 залученням практичних працівників правоохоронних органів відповідних напрямків і галузей діяльності;
- проведення комплексних кримінологічних досліджень, що мають адресний характер «за вимогою» відповідних суб'єктів протидії економічній злочинності;

- забезпечення реального впровадження результатів наукових досліджень у практику протидії економічній злочинності;

- формування науково-правової культури у суб'єктів кримінологічного забезпечення економічної безпеки;

- проведення наукових досліджень із вивчення та аналізу зарубіжного досвіду у сфері протидії економічній злочинності та окреслення шляхів імплементації кращих його положень в національне законодавство;

- запровадження практики онлайн громадського обговорення законодавчих пропозицій та нормативних актів 3 економічних питань, що перебувають на розгляді у Верховній Раді України;

- створення окремої науково - дослідної структури з координації діяльності всіх наукових, дослідницьких та експертних установ на основі принципів спеціалізації та інтеграції з метою підвищення ефективності наукового забезпечення протидії економічній злочинності.

Удосконалення заходів та прийомів кримінологічного впливу в межах механізму, що розглядається, є одним із завдань як науки, так і сучасної правоохоронної практики. У сукупності вони складають систему впливу на механізм кримінологічного забезпечення економічної безпеки й охоплюють предметну сферу діяльності відповідних суб’єктів їі здійснення.

\section{Висновки та перспективи подальших досліджень}

Наукове забезпечення протидії економічній злочинності, особливо в період реформаційної розбудови правоохоронних органів та загострення соціальних протиріч, повинно базуватися на реаліях сьогодення, постійно оновлюватися у відповідності до змін, що відбуваються в суспільстві, із використанням спільного потенціалу теоретиків та практиків, з метою оптимізації означеної діяльності.

Наука завжди іде попереду практики, забезпечує наукове осмислення соціальних 


\section{Кримінальне право, кримінальний процес та криміналістика}

процесів та законів розвитку суспільства, їх різносторонне дослідження, слугує міцною основою подолання кризи в системі протидії злочинності. А процес взаємодії науки i практики породжує концептуально нові шляхи протидії економічній злочинності в iï сучасних проявах та транснаціональній поширеності. В цих умовах успішне вирішення проблем стратегічного управління економічною безпекою країни неможливе без наукового обгрунтування, вироблення кримінологічних прогнозів розвитку криміногенної ситуації як в цілому по країні, так і в окремих регіонах.

Враховуючи викладене, безсумнівною 6 необхідність інтенсифікації наукової розробки широкого кола актуальних питань протидії економічній злочинності, як одній з основних загроз економічній безпеці держави.

\section{Лiтература}

1. Литвинов О.М. Настільна книга ад'юнкта та здобувача наукового ступеня (зі спеціальності 12.00.08 - кримінальне право та кримінологія; кримінально-виконавче право): науково-практичний посібник / О.М. Аитвинов, Е. С. Назимко; за заг. ред. д.ю.н., проф. О.М. Аитвинова. Донецьк: ВД «Кальміус», 2014. 260 с.

2. Бандурка О. М., Аитвинов О. М. 3лочинність як об‘єкт феноменологічного аналізу. Право і безпека. 2015. № 3 (58). С. 6-10.

3. Дрьомін В.М. Сучасні функції кримінології. Науковий вісник Міжнародного гуманітарного університету. 2017. № 29 (том2) c. 64-67.

4. Василевич В.В., Джужа О.М. Головні напрями розвитку сучасної кримінології. Науковий вісник Національної академії внутрішніх справ. 2015. № 1, с. 71-81

5. Методологія науки кримінологіï : https://visnikkau.webnode.com.ua/news/ metodologiya-nauki-kriminologiii/

6. Головкін Б. М. Корислива насильницька злочинність в Україні: феномен, детермінація, запобігання : монографія. Харків, Право, 2011. 432 с.

7. Крижановський А. Методологічні та методичні засади кримінологічного обслу-

\section{SUMMARY}

The article is focused on determining the role of science in the theory and practice of criminological provision for the state's economic security.

The author has emphasized on the urgency of studying this area of criminological provision, which is due to reform changes and constant legislative changes in regulating the issues related to economic security. A number of basic measures that should be implemented in the field of scientific and methodological provision of the state's economic security has been highlighted.

The special importance of close interaction between science and practice in combating crime on the way to ensure economic security has been emphasized. The author has noted that nowadays implementation of scientific research results into the practical activity of the employees of the National Police of Ukraine should be considered as a significant factor in improving the efficiency of law enforcement activities, which unfortunately, is not fully used in combating crime.

Particular attention has been paid to the need to intensify the scientific development of a wide range of relevant issues in the field of combating economic crime, as one of the main threats to the economic security of the state on the one hand, and forming a criminal policy on the basis of a qualitatively new scientific criminological basis - on the other hand.

The priority of state support for the development of scientific activity (in particular, departmental) in Ukraine, the need to ensure the participation of researchers in forming the main directions of national policy in the field of scientific development, has been emphasized.

The author has outlined the range of directions perspective for further scientific research, in particular: mathematical provision, motivational, anti-crisis, economic, technological, software and other types of ensuring the economic security of the country.

Key words: economic security, economic crime, criminological provision, science, scientific provision, comparative criminology, scientific potential, scientific activity, implementation.

говування діяльності територіальних органів національної поліції. Lviv Polytechnic National University Institutional Repository http://ena.lp.edu.ua c. 128-131. 